University of Michigan Law School

University of Michigan Law School Scholarship Repository

Articles

Faculty Scholarship

1923

\title{
Legislation in Vague or General Terms
}

Ralph W. Aigler

University of Michigan Law School

Available at: https://repository.law.umich.edu/articles/797

Follow this and additional works at: https://repository.law.umich.edu/articles

Part of the Courts Commons, Legislation Commons, and the State and Local Government Law Commons

\section{Recommended Citation}

Aigler, Ralph W. "Legislation in Vague or General Terms." Mich. L. Rev. 21 (1923): 831-51.

This Article is brought to you for free and open access by the Faculty Scholarship at University of Michigan Law School Scholarship Repository. It has been accepted for inclusion in Articles by an authorized administrator of University of Michigan Law School Scholarship Repository. For more information, please contact mlaw.repository@umich.edu. 


\title{
MICHIGAN LAW REVIEW
}

\begin{tabular}{lll}
\hline Vol. XXI & JUNE, 1923 & No. 8 \\
\hline
\end{tabular}

\section{IIEGISLATION IN VAGLE OR GENERAL TERMS}

\author{
By Ralph W. Aicler*
}

$F^{\mathrm{OR}}$ some reason, probably in part the increasing complexity of our life and relationships, but more largely, perhaps, the growing tendency to regulate everybody. and everything by positive law, the courts have been called upon with increasing frequency to pass upon the effectiveness of statutes and ordinances phrased in indefinite terms. In a very interesting and valuable paper, Professor . Freund has pointed out the weakness and strength, on the one hand, of legislation in general terms, and on the other hand, legislation in which the rule of conduct is attempted to be laid down with precision. ${ }^{1}$ His interest apparently lay in the effect of the legislation - from the point of view of its administration. It may be not without interest to consider how far legislative bodies may go in the direc-

- tion of generality without impairing the zalidity of their product.

Most courts have approached this problem as one of the constitutionality of the challenged provision. It is believed, and the grounds for this belief will be pointed out later herein, that in many of the cases in which legislation is declared of no effect because of vagueness or uncertainty in the language used there is no need of tying the conclusion to any particular constitutional inhibition. An interesting example of this is presented in a recent decision by the Supreme Court of Ohio." An employee there sought to hold his

* University of Michigan Law School.

${ }^{3} 30$ I'ALE L. Jork. 437.

= Patten v. Aluminum Castings Co., 136 N. E. 426. 
employer to his common law liabilities, despite his compliance with the Workmen's Compensation Act, on the ground that under that act and the constitutional provision under which the act was passed an employee was saved his ordinary rights of action when the injury arose "from failure of the employer to comply with any lawful requirement for the protection of the lives, health and satety of employees." It was contended that in the case before the court thedefendant employer had failed to observe a "lawful requirement" in not providing scaffolding as required in the following statute: "Whoever, employing or directing another to do or perform labor in erecting $* * *$ knowingly or negligently furnishes, erects or causes to be furnished for erection for and in the performance of said labor unsuitable or improper scaffolding *** which will not give proper protection to the life and limb of a person so employed or engaged, shall be fined $* * *$ or imprisoned," etc. ${ }^{3}$ It was held that the quoted words did not lay down a "lawful requirement," a bare majority of the court apparently being of the opinion that the language was too vague. By reason of the fact that under the Ohio Constitution ${ }^{5}$ at least six out of the seven members of the court must concur in order to declare a statute unconstitutional, it is clear that the result was reached independently of any constitutional restriction upon legislative action. ${ }^{\circ}$

Italics are the writer's.

4 In an opinion in which Robinson and Matthias, JJ., concurred, Jone's, J., used the following language: "*** How would the defendant in error be able to ascertain the exact requirement made of him as an employer in order to escape civil and criminal liability? Manifestly, it would be impossible for him to ascertain the extent of his duty until after a jury, by its verdict, had determined that the employer had failed to provide a suitable scaffolding. What would be an 'unsuitable or improper' scaffolding? The cmployer might endeavor honestly to conform to the provisions of the statute relating to suitableness, only to find later, that a jury declared otherwise, and that he had not performed his duty in that regard. Even different juries, in similar cases and upon the same facts, might not agree in their conclusion as to what would be suitable. No criterion of specific conduct is exacted by the law. No definite requirement is made. It prescribes merely a general course of conduct on the part of the employer in requiring him not to furnish scaffolding that is unsuitable and improper, and wlich will not give proper proiection to the life and limb of the employe."

s Art. IV, § 2, Ohio Constitution, as amended in 1912.

- Other Ohio cases will be referred to infra. 
At the outset, there may be set aside those cases which may arise under the constitutional requirement that laws shall be published only in the English language.' An unusual case involving this question was recently decided by the California Supreme Court. ${ }^{9}$ In habeas corpus proceedings the validity of an act of the California legislature providing that "The acts technically known as fellatio and cumilingus are hereby declared to be felonies," was challenged. The court, Wilbur, J., dissenting, concluded that the words in italics were not English. Apparently, the court was quite prepared to declare the statute void for uncertainty if the other ground were not deemed sufficient. The concurring opinions of Victor E. Shaw, J., and Angellotti, C. J., were upon the latter ground. ${ }^{\circ}$ But in Piople $\therefore$. Goldberger ${ }^{10}$ it was held that a statute making it an offense falsely to represent meat exposed for sale to be "kosher" was valid; the word has an ascertainable meaning, at least in New York, though not generally known. In the California case the court fouml itseif unable to attach a reasonably definite meaning to ihe italicized words either as Latin or English..11

iThis scems a not unustial requirement.

EIn re Lockett, $179 \mathrm{Cal}$. $58 \mathrm{I}$.

o The court states that "no authority has been called to our attentiun - whereiy any law has been declared unconstitutional because not expressed in the English language *** Authority may be found, however, ior the rejection of pleadings not drawn in English when the statutes prescribe that language, and surely the constitutional requirement that English and no other language may be used in our laws should receive a construction at lcast as strict as that applied to such statutes." The court cites Siate $r$ Town of Jericho. 40 V't. 12I ; Hedges v. Boyle, 7 N. J. L. 68; People $v$. Ah Sum, 92 Cal. 648.

${ }^{10} 163$ N. Y. Supp. 663.

11 "That the legislature, in the exercise of its power to define crimes and to provide for the punishment of offenses, should make laws tending to the suppression of sins against decency is most commendable, and that statutes should be drawn in language to offend the sensibilities of normal people to as small degree as possible is a truth none should gainsay; yet so important is the liberty of the individual that it may not be taken away everr from the most debased wretch in the land, except upon conviction of a crime which has been so clearly defined that all might know in what act or omission the violation of the law should consist. For this reason the people, through their constitution. have wisely decreed that all laws, all official writings, should be preserved and published in the English language. It is also true that in construing statutes courts should readily regard the words from other languages 
There may also be set aside as perfectly clear those cases wherein are involved statutes from which vital parts have been omitted or there has been a failure to use language which is intelligible. If a legislature were to string together after the phrase, "Be it enacted," words appearing in succession in a dictionary, no court in declaring the enactment of no effect would need to resort to any provision either of the national or state constitution. Cases so extreme as this probably never would arise, but some legislative enactments, when courts have been called upon to determine their meaning, have not proved to be much better. ${ }^{12 *}$ In an early Pennsylvania case ${ }^{13}$ there was involved a statute which provided that the state which owned 3,750 shares of the state bank should have as many votes "as though the same were held by individuals." An earlier statute had provided for a graduated number of votes in bank elections where shares were held by individuals. The court declared the first mentioned statute void for uncertainty, for there was absolutely no way of determining how many individuals the state should be considered as representing, Gibson, C. J., saying that seldom, if ever, is legislation found so devoid of certainty. In State v. Partlow ${ }^{13}$ the legislature had made it an offense to sell liquor within three miles of "Mount Zion Church in Gaston County." On the trial of one accused of selling liquor within the prohibited area it appeared that there were two churches in that county bearing the name used by the legislature, and the court held the statute void, there being no per-

as being Anglicized and, therefore, as escaping the constitutional objection in all cases where they had come into common use or were easily understood by reference to lexicons commonly accessible, and that, in the interests of decency, courts should sanction the use of such words, euphemistically employed to describe offenses against morality, thus avoiding the bald nastiness involved in the use of the vernacular, if the words in the statutes from other languages than our own, bore clear definite meanings easily ascertained. This court should do much to uphold the legislature in its efforts to avoid shocking specifications in the definitions of crimes of indecency. But the faults of the statute before us arise from the circumstances that not only is the word 'fellatio' one not found in the English language, but is not a word having a definite, technical meaning either in law or in psychopathology:" Melvin, J., in 179 Cal. 583,584 .

112 Naturally it is quite impossible to draw a precise line of distinction between this type of case and those to be discussed later on.

12 Commonwealth v. Bank, 3 Watts \& S. 173.

2391 N. C. 550. 
missible way of determining which church was meant. ${ }^{14}$ In the note will be found other cases along this line. ${ }^{15}$

The Iowa court had occasion, a few years ago, to wrestle with a problem in some respects like the one to which reference has just been made. ${ }^{10}$ A statute had been passed requiring the rays of automobile headlights to be higher than forty-two inches from the ground at a distance of seventy-five feet ahead of the lights. Obviously, a mistake had been made in omitting the word "not." The accused had been prosecuted, evidently in a friendly proceeding, in order to secure an adjudication as to the meaning of the statute. The court was satisfied that the language did not correctly represent the will of the legislature and held there was failure of legislation, stating that they could not read the omitted word into the statute, for that would be usurpation of legislative power. The act certainly was not meaningless as in the cases referred to above; it was quite clear what the legislature had said. It is, then, of more than passing interest that the court which was so careful to avoid encroachment upon the powers of another arm of the state government that it refused to read into the statute the word "not" felt itself free to nullify the

14 The testimony of the State Senator who introduced the bill was rejected, and rightly so, it would seem.

1s Johnston v. State, 100 Ala. 32 (statute provided that for carrying away a "registered dog" the guilty party should be punished as in other cases of larceny. Held void for uncertainty, since no way of telling whether the punishment was to be as in grand or petit larceny); Jones v. Lawson, 143 - Ark. 83 (Act creating special school district did not give any ascertainable boundaries); Hallam v. Coker, 147 Ark. 73 (Statute in creating improvement district and providing for assessments, etc., stated the nature of the improvement as "building, repairing relocating or constructing highway bridges across the Caddo River and Little Missouri River and such other streams as in the opinion of the commissioners need bridging, at such points across said streams as in the opinion of the commissioners hereinafter may select." Held too vague); Railroad Comm v. Grand Trunk, etc. Ry. Co., 179 Ind. 255 (Requirement under penalty that railroads have "an approved block system." Held ineffective); Pizatti's Succ., I4I La. 645 (Adoption statute not providing how adoption might be accomplished held ineffective); State v. Ashbrook, 154 Mo. 375 (License Act held hopelessly uncertain); Brown v. State, 137 Wis. 543 (Provision for penalty for physician's failure to register before a certain time with Registrar held void because the statute failed to prescribe who the Registrar should be); Hilbuin v. Ry. Co., 23 Mont. 229 (Assessment vote provision).

${ }^{16}$ State v. Clairbourne, 185 lowa 170. 
action of the legislature completely. On the other hand, in Wilson $v$. Going 17 the court was willing to add the letter "s" to the word "parent" in a statute providing that "a child born before wedlock becomes legitimate by the subsequent marriage of its parent."18

As stated above, it is next to impossible with any degree of certainty or satisfaction to classify the cases except within the very broadest limits. It may not be without value to examine the cases of a single jurisdiction with a view to determining whether any workable conclusions as to the treatment by the courts of uncertain legislation may be derived therefrom. For this purpose, the cases in the federal courts will be considered. Automobile safety legislation and regulations regarding the practice of certain professions have been frequent sources of troublesome questions along these lines, and the cases involving these problems will be then taken up. After that, reference will be made to a variety of unclassifiable decisions.

\section{Federal Decisions}

One of the earliest cases involving the problem is The Schooner Enterprise, ${ }^{10}$ in which $\mathrm{Mr}$. Justice Livingston concluded that an act of Congress under which proceedings for forfeiture of a ship and cargo had been instituted was too vague for such result. After pointing out that penal statutes are to be construed so as not to be extended, by what may be thought their spirit or equity, to offenses other than those which are specially and clearly described and provided for, and that courts are necessarily obliged to inquire more or less into the intentions of the legislature, however clearly a law be expressed, said:

"For although ignorance of the existence of a law be no excuse for its violation, yet if this ignorance be the consequence of an ambiguous or obscure phraseology, some indul-

${ }^{17} 210$ Pac. 1014 (Okla., 1922).

18 It was argued that in a legal sense, however, it may be in fact, an llegitimate child had but one parent, the mother, and that, therefore, the statute meant that on the mother's marriage the child should be legitimatized. Although this contention was not wholly unreasonable the fact remains that there was occasion for interpretation on the very reading of the statute, which may place the case on a basis somewhat different from the Iowa case.

20 I Prine (C. C.) 32. 
gence is due to it. It should be a principle of every criminal code, and certainly belongs to ours, that no person be adjudged guilty of an offense unless it be created and promulgated in terms which have no reasonable doubt of their meaning. If it be the duty of a jury to acquit where such doubts exist concerning a fact, it is equally incumbent on a judge not to apply the law to a case where he labors under the same uncertainty as to the menning of the legislature."

In Railroad Co. $\approx$. Railroad Comm. ${ }^{20}$ a Tennessee statute providing penalties for taking "unjust and unreasonable compensation" and for making unjust and unreasonable discriminations was held bad because the guilt or innocence of an accused would be left to the finding of a jury and not upon a construction of the statute. ${ }^{21}$ And in Tozer $v$. United States, ${ }^{22}$ in which the provision of the Interstate Commerce Act forbidding "undue preferences" was held not sufficiently specific to make anything thereunder a crime, Mr. Justice Brewer used the often quoted language:

"But in order to constitute a crime, the act must be one which the party is able to know in advance whether it is criminal or not. The criminality of an act cannot depend upon whether a jury may think it reasonable or unreasonable. There must be some definiteness and certainty." ${ }^{2 s}$

${ }^{20} 19$ Fed. 679.

${ }^{21}$ Not only would the jury be called upon to determine whether the ac.cused had in fact done the things complained of, but they would also have to pass upon whether the legislature's inhibition was broad enough to include such act.

2252 Fed. 917.

${ }^{23}$ The court here quoted from Railway Co. v. Dey, 35 Fed. 866,876 , as follows: "But in order to constitute a crime, the act must be one which the party is able to know in advance whether it is criminal or not. The criminality of an act cannot depend upon whether a jury may think it reasonable or unreasonable. There must be some definiteness and certainty. In the case of Railway Co. v. Dey, 35 Fed. Rep. 866, I had occasion to discuss this matter, and I quote therefrom as follows: 'Now, the contention of complainant is that the substance of these provisions is that, if a railroad company charges an unreasonable rate, it shall be deemed a criminal, and runished by a fine, and that such a statute is too indefinite and uncertain, no man being able to tell in advance what in fact is, or what any jury will find to be, a reasonable rate. If this were the construction to be placed upon this act as a whole, it would certainly be obnoxious to complainant's criti- 
Again, in James $v$. Boz'man, 24 the same distinguished judge, quoting from Mr. Chief Justice Waite in United Stat's i'. Rese,": used language frequently invoked:

"It would certainly be dangerous if the leyislature could set a net large enough to catch all possible offenclers. and leave it to the courts to step inside and say who could be rightfully detained and who should be set at large. This would, to some extent, substitute the judicial for the legislative department of the government."28

That the doctrine thus laid down is unsound is pointed out by Mr. Justice Holmes in Nash v. United States, ${ }^{27}$ which involved the overruling of a demurrer to an indictment charging conspiracy in restraint of trade under the Sherman Act. It was contended that since the decisions in the Standard Oil and Tobacco cases had injected the so-called "rule of reason" into the operation of the stat-

cism, for no penal law can be sustained unless its mandates are so clearly expressed that an ordinary person can determine in advance what he may and what he may not do under it. In DwAr. Sr. 652, it is laid down 'that it is impossible to dissent from the doctrine of Lord Coke that the acts of parliament ought to be plainly and clearly, and not cunningly and darkly, penned, especially in legal matters.' See, also, U. S. v. Sharp, Pet. C. C. 122; The Enterprise, I Paine, 34; Bish. ST. Crimes, § 41; LIEB. Herm. 156. In this the author quotes the law of the Chinese Penal Code, which reads as follows: 'Whoever is guilty of improper conduct, and of such as is contrary to the spirit of the laws, though not a breach of any specific part of it, shall be punished at least forty blows; and when the impropriety is of a serlous nature, with eighty blows.' There is very little difference between such a statute and one which would make it a criminal offense to charge more than a reasonable rate. See amother illustration in Ex Parte Jackson, 45 Ark. 158."

2190 U. S. 127.

3502 U. S. 214

so Similar language is used in Ry. Co. v. Daniels, 90 Ga. 610. James v. Bowman arose upon a prosecution for bribery at an election, and it was held that the Act of Congress under which the accused was charged would not warrant a conviction. Another election case is United States v. Brewer, 139 U. S. 278, wherein it is said that "Laws which create crimes ought to be so explicit that all men subject to their penaltics may know what acts it is their duty to avoid. Before a man can be punished, his case must be plainly and unmistakably within the statute." U. S. v. Sharp, I Pet. (C. C.) 118 , was cited; it was there held that a statute making it an offense to "make a revolt" was too vague for enforcement.

3229 U. S. 373 . 
ute, it had thereby become so vague as to be inoperative on its criminal side; that by those cases it had been established that only such contracts and combinations were prohibited as, by reason of intent or the inherent nature of the contemplated acts, prejuduce the public interests ${ }^{28}$ by unduly restricting competition or unduly obstructing the course of trade; and that it therefore followed that the crime thus defined by the statute contains in its definition an element of degree as to which estimates may differ, with the result that a man might find himself in prison because his honest judgment did not anticipate that of a jury of less competent men. After referring to the language of Mr. Justice Brewer in the Tozer case, Mr. Justice Holmes said:

"But apart from the common law as to restraint of trade thus taken up by the statute, the law is full of instances where a man's fate depends on his estimating rightly, that is, as the jury subsequently estimates it, some matter of degree. If his judgment is wrong, not only may he incur a fine or a short imprisonment, as here; he may even incur the penalty of death."28

29 See Adelaide S. S. Co. v. Rex, 14 C. L. R. 36 (Aus., IgII), 15 C. L. R. 65. [1913] A. C. 78I.

29 "An act causing death may be murder, manslaughter, or misadventure according to the degree of danger attending it by common experience in the circumstances known to the actor. "The very meaning of the fiction of implied malice in such cases at common law was, that a man might have to -answer with his life for consequences which he neither intended nor foresaw.' Commonwealth v. Pierce, 138 Massachusetts, 165, 178. Commonwealth v. Chance, 174 Massachusetts, 245, 252. 'The criterion in such cases is to cxamine whether common social duty would, under the circumstances, have suggested a more circumspect conduct.' I East P. C. 262 . If a man should kill another by driving an automobile furiously into a crowd he might be convicted of murder however little he expected the result. See Reg. v. Desmond, and other illustrations in STEPHEN, Dic. CrIM. LAw, art. 223, [Ed. 1], p. I46. If he did no more than drive negligently through a strect he might get off with manslaughter or less. Reg. v. Swindall, 2 C. \& K. 23; Rex v. Burton, I Strange, 481 . And in the last case he might be held although he himself thought that he was acting as a prudent man should. See The Gernunnic, 196 ᄂ. S. 589,596 . But without further argument, the case is very nearly disposed of by Waters-Pierce Oil Co. v. Texas (No. I), 212 U. S. 86, I09, where Justice Brewer's decision and other similar ones were cited in vain. We are of opinion that there is no constitutional difficulty in the way of enforcing the criminal part of the act." 
It was accordingly held that the indictment was properly sustained. It is important to notice that apparently there was no notion that any particular constitutional provision or question was involved.

In the following year the same court, speaking through the same distinguished judge, had occasion to set limits in turn upon its recent pronouncement. ${ }^{30}$ A statute of Kentucky made "any combination lawful unless for the purpose or with the effect of fixing a price that was greater or less than the real value of the article" involved; and this "real value" was to be its market value "under normal market conditions." It was held that the statute was unenforceable, the Nash case being distinguished on the ground that there members of the public in shaping their conduct so as to accord with the legislative direction dealt with actual conditions, while under the Kentucky law one would have to guess what prices would be in an imaginary world, and that under penalty of indictment. ${ }^{32}$ Although the opinion does not tie up the case to any constitutional provision, the attorneys had argued that there was a violation of the Fourteenth Amendment. In view of the fact that the court retained the case for adjudication, it is clear that here the case is made to turn on a constitutional limitation.82

In Fox v. Washington, ${ }^{33}$ a statute of the State of Washington making it an offense to edit printed matter tending to encourage and advocate "disrespect for law" was declared free of constitutional

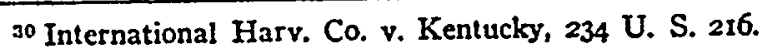

32 "** * It [the Nash case] goes no further than to recognize that, as with negligence, between the two extremes of the obviously illegal and the plainly lawful there is a gradual approach and that the complexity of life nakes it impossible to draw a line in advance without an artificial simplification that would be unjust. The conditions are as permanent as anything human, and a great body of precedents on the civil side coupled with familiar practice make it comparatively easy for common sense to keep to what is safe. But if business is to go on, men must unite to do it and must sell their wares. To compel them to guess on peril of indictment what the community would have given for them if the continually changing conditions were other than they are, to an uncertain extent; to divine prophetically what the reaction of only partially determinate facts would be upon the imaginations and desires of purchasers, is to exact gifts that mankind does not possess" (p. 223).

32 This is the first one of the cases referred to so far in which this is true.

ss 236 U. S. 273 . See case below in 71 Wash. 185. 
objection, the state court having read the statute "as confined to encouraging an actual breach of law." What the decision would have been without such limited meaning is perhaps doubtful. Miller v. Strahl, ${ }^{35}$ which arose on a civil action against a hotel man charged with negligence in that, inter alia, he had failed to comply with a Nebraska statute providing that hotels must give "notice of the same [fire] to all guests and inmates thereof at once, and to do all in their power to save such guests and inmates," a fine being specified on violation, it was held that the rule of the Nash case rather than that of the International Harvester Co. applied, and that, therefore, the statuti did not amount to a denial of "due process." This case and the Nash case were relied on in upholding, in Omaechevarria $v$. Idaho, ${ }^{30}$ a conviction for violation of a statute prohibiting herding and grazing sheep "on any cattle range ***, or upon any range usually occupied by any cattle grower." The court deemed the statute not so uncertain as to violaie the Fourteenth Amendment. But in United States v. Cohen Grocery Co. ${ }^{37}$ the provision of the Lever Act making it unlawful for any person "wilfully $* * *$ to make any unjust or unreasonable rate or charge in handling or dealing in or with any necessaries $* * *$ or to exact excessive prices for any necessaries" was held bad as not prescribing any ascertainable standard of guilt and as being inadequate to inform the accused of the nature and cause of the accusation. The court declared that if the statute were upheld

“*** it would result, in fiew of the text of the statute, that no standard whatever was required, no information as to the nature and cause of the accusation was essential, and that it was competent to delegate legislative power, in the very teeth of the settled significance of the Fifth and Sixth Amendments and of other plainly applicable provisions of the Constitution." 33

34 See Ex parte Jackson, 45 Ark. 158.

35239 U. S. 426.

${ }^{80} 246$ U. S. 343.

${ }^{37} 255$ U. S. 8I. Pitney and Brandeis, J.J., dissented from the court's view. See 255 U. S. III.

${ }^{38}$ Cases like Nash v. U. S., Miller v. Strahl, etc., were distinguished on the ground that "from the text of the statutes involved or the subjects with which they dealt, a standard of some sort was afforded." In addition to 
The latest decision of the Supreme Court bearing on this question appears to be Lovy Leasing Co. $v$. Siegel, ${ }^{30}$ in which the New York rent law providing that "it shall be a defense to an action by a landlord that the rent demanded is unjust and unreasonable, and the agreement under which it is sought to be recovered is oppressive," was upheld against an attack on the score of indefiniteness. Mr. Justice Clarke, in delivering the opinion of the court, said that

"The standard of the statute is as definite as the "just compensation' standard adopted in the Fifth Amendment to the Constitution, and therefore ought to be sufficiently definite to satisfy the Constitution."

It was pointed out that the Cohen Grocery Co. case was not applicable, for it dealt with definitions of crime. ${ }^{10}$

From these cases, perhaps, certain tentative conclusions may be drawn:

(1) The federal courts will declare congressional action ineffective because of vagueness simply on the ground that there has been

International Harvester Co. v. Kentucky, the court refers for support to Collins v. Kentucky, 234 U. S. 634, 637; American Seeding Machine Co. v. Kentucky, 236 U. S. 660,662 ; United States v. Pennsylvania R. R. Co., 242 U. S. $208,237-238$.

${ }^{30} 257$ U. S.,- 42 Sup. Ct. Rep. 289.

${ }^{10}$ There have been several fairly recent decisions by the lower federal courts. In U. S. v. Brewers' Ass'n, 239 Fed. I63, a statute making it an offense "To make a money contribution" was upheld, the court saying that the objection of uncertainty here raised no constitutional question, but only one of interpretation. In Sears, Roebuck \& Co. v. Fed. Trade Comm., 258 Fed. 307, the words "unfair methods of competition" in the Federal Trade Commission Act were not too vague; common law standards could be looked to, though the act need not be construed as limited to practices condemned by common law when the act passed. And the Lever Act had been viewed each way, as to the question here considered, in the lower courts. See Weed \& Co. v. Lockwood, 266 Fed. 785; U. S. v. Bernstein, 267 Fed. 295. A Missouri statute of 1917, requiring railroad companies and others engaged in building or repairing cars to erect and maintain buildings to protect employees while at work "from exposure to cold, rain, sleet, snow, and all inclement weather," under penalty of a fine, but excepting "light repairs" such as can be made to cars in switching yards "in thirty minutes" or less "or" in less time than would be required to switch such car or cars to the repair building," was held violative of the Missouri Constitution and probably of the Fourtcenth Amendment, in Wabash Ry. Co. v. O'Bryan, 285 Fed. 583. 
no ascertainable rule of conduct prescribed." When the court rests its decision on constitutional grounds, the Fifth and Sixth Amendments are invoked."

(2) State legislation declared invalid by the federal Supreme Court on appeal from the state courts on the ground of vagueness must rest on constitutional grounds, - the Fourteenth Amendment. That is the only way the case can get from the state court to the Supreme Court. ${ }^{43}$

(3) The earlier declarations as to the certainty requisite in valid legislation were not sound, or, perhaps, merely unfortunately worded.44

(4) Criminal legislation is scrutinized more closely in this regard than are purely civil enactments. ${ }^{45}$

(5) There must be some ascertainable standard by which the meaning of the language in question may be determined. This may be either in the act itself or in the nature of the subject matter."

\section{Automobile Legislatron}

In not a few states there are speed laws in substantially the following form:

11 In U. S. v. Brewers' Ass'n, 239 Fed. 163, where "To make 2 money contribution" was held sufficiently definite, the court said that the objection of uncertainty raised no constitutional question, only one of interpretation. See also the many cases above referred to in which the decision was not rested on any constitutional ground.

42 Sce, for example, the Cohen Grocery Co. case, supra. of this.

43 International Harvester Co. v. Kentucky, supro, is a good example

34 As pointed out by Mr. Justice Holmes in Nash v. United States, supra.

15 Levy Leasing Co. v. Siegel, supra, per Clarke, J.

16 See remarks of Mr. Chief Justice White in the Cohen Grocery Ca. case. An example of a legislative act containing in meticulous detail the mcans of determining a violation is found in City of Rochester v. Macauley, etc., Co., 199 N. Y. 207. With the smoke ordinance involved in this case might well be compared the general language of a recent ordinance of Ann Arbor: "Emission of dense smoke from *** which smoke contains soot, cinders, or other substance in sufficient quantities to be deleterious to health or an inconvenience to the general public * * is declared a public nuisance." There are other provisions that the ordinance shall not apply to emission of smoke, etc., for six minutes of any hour when a fire-box or furnace is "necessarily" being cleaned or fired, nor to manufacturers obliged to use an "open fire" in the conduct of their business. 
"Whoever operates a motor vehicle or motorcycle on the public roads or highways at a speed greater than is reasonable or proper, having regard for width, traffic, use, and the general and usual rules of such road or highway, or so as to endanger the property, life, or limb of any person $* * *$ shall be fined," etc.

Many times these laws have been attacked on the basis of their vagueness. In most of the cases the legislation has been upheld. ${ }^{47}$ In Georgia and Pennsylvania are to be found decisions reaching the opposite conclusion. ${ }^{48}$ And in Texas a statute forbidding headlights projecting forward "a light of such glare and brilliancy as to seriously interfere with the sight of, or temporarily blind the vision of, the driver of a vehicle approaching," etc., was held fatally vague and indefinite.

\section{Legislation Regulatinc Practici: of Professions}

The common requirement that applicants for admission to the bar must be of good moral character has never, so far as the writer is aware, been attacked on the ground of vagueness, though it must be recognized that the test is decidedly vague and difficult of practical administration. Statutes providing for disbarment frequently specify among the grounds therefor "unprofessional conduct." The Ohio statute provides for suspension or removal of attorneys "for misconduct in office *** or unprofessional conduct involving moral

47 Hood v. W. Furniture Co., 200 Ala. 607 (civil case-court said common law limited speed same way); Ex parte Daniels, 183 Cal. 636 (court said more liberality is being manifested regarding vague terms in criminal statutes because administration of the criminal law no longer is so harsh); State v. Campbell, 82 Conn. 671; Fitzsimmons v. Snyder, 181 Ill. App. 70; People v. Beak, 291 Ill. 449 (fact that act contained specification of certain speeds which would be deemed prima facie unreasonable was deemed helpful, if not decisive, in saving the legislation); Smith v. State, Ind.

115 N. E. 943; Emery v. Wheeler, 231 Mass. 243; People v. Dow, 155 Mich. II5 (specific maximum speed in "business portion"); State v. Waterman, 112 Minn. 157; Schultz v. State, 89 Neb. 34; State v. Schaeffer, 96 Oh. St. 215; U. S. v. Knight, 26 Philippines, 217; Christensen v. Harms, 38 S. D. 360; Sloan v. Pasche (Tex.), 153 S. W. 672 (civil case-court said as penal statute it was unconstitutional).

1s Strickland v. Whatley, $142 \mathrm{Ga}$. 802 (as penal statute the act was too vague, but it was not too indefinite to furnish a rule of civil conduct); Hayes v. State, 11 Ga. App. 371 ; Comm. v. Davidson, 21 Pa. Dist. Ct. 885. 
turpitude."'s In Oklahoma "the wilful violation of any of the duties of an attorney or counselor" is a ground for suspension or revocation of license. ${ }^{50}$ And in Nevada an attorney may be removed or suspended "For misconduct in office, or for good cause shown." The courts appear to have found no difficulty in applying such general provisions. Of course, attorneys being officers of the court and the judges being experienced lawyers supposedly familiar with the standards and ethics of the profession, such result is not surprising.

In Heacitit $\approx$. Board of Medical Examiners ${ }^{32}$ there was involved a statute which empowered the Board of Examiners to revoke physicians' certificates for unprofessional conduct, defining such conduct as consisting, inter alia, of "all advertising of medical business in which grossly improbable statements are made." The court declared the statute too uncertain. ${ }^{33}$ In Kentucky and the District of Columbia it has been decided that provisions for revocation of licenses of physicians for "unprofessional" or "unprofessional and dishonorable" conduct are ineffective. ${ }^{\text {jt }}$ This view, however, is not uniformly accepted.".5 If umprofessional conduct is by the statute ticd up to legally recognized standards of conduct the courts find no difficulty in supporting and applying such legislation." A statute

\footnotetext{
$10 \mathrm{GEN}$. Codr., Sic. 1707.

${ }^{50}$ Comiphlid Stits., Scc. 4106.

iI Rev. Laws, Sec. jII.

52 I48 Cal. 590.

63 The statute appears to have been amended so as to provide that unprofessional conduct shall mean $\cdots * *$ Third. Ali advertising of medical business which is intended or has a taidency to deceive the public or impose upon credulous or ignorant persons, and so be harmful or injurious to public morals or safety." This was upheld in Glass v. Doard of Med. Examiners (Cal. App.), 195 Pac. 73, iollowing State Board v. Macy, 92 Wash. 614, which declared valid a statute from which the amended California act evidently was copied. In these statutes there was involied the element of deception oi the ptiblic, and that appears to have given the couris somethirg to tie to.

s4 Matthews y. Murphy, 23 Ky. L. Rep. 750; Czarra v. Medical Supervisors, 25 App. Cas. (D. C.) +43 (Sixth Amendment relied on).

"s See State v. State Medl. Jixam. Board, 32 Minn. 324, 34 Mimn. 357; Neffert $v$. l'acker, 60 lians. $; 10,105$ U. S. 625; Sinith v. Med. Exam'rs, 140 Ia. 66.

* State Med. Honrd v. MeCrary, 95 Ark. 511 ; Wilite $\checkmark$ Andrew, Colo. -, I97 Pac. $56_{4}$; State Board of Med. H.xuin'rs v. Macy, 92 Wash. 614; Glass v. Eoard of Med. Exam'rs, - Cal. I 1p. -, 195 Pac. 73; Board oi
} 
which provides for revocation of license for what might be termed infra-professional misconduct or breach of ethics would probably not be upheld.: The courts in such cases very naturally feel themselves much more at sea than in the disbarment cases.

A Missouri statute provided that the State Board of Dental Examiners should have power "to revoke and annul any original or renewal license or registration for fraud, deceit, or misrepresentation in the practice of dentistry, or for gross violations of professional dutics." "ss 'The Board having revoked the relator's license for violations of this statute, mandamus proceedings were instituted. ${ }^{\circ 0}$ It was claimed that the statute was roid for uncertainty. In passing on this contention the court said:

"We are unable to lend our concurrence to these views of the learned counsel for the relator. The words of the statute, 'fraud, deceit or misrepresentation,' have a well-defined meaning not only at common law but also in all the branches of English literature; and when the legislature used them in this statute it is to be presumed that it used them in their plain, ordinary and usual sense."

After discussing the meaning of fraud, deceit and misrepresentation, the court observes that it had been argued that since the statute also used the words "gross violations of professional duties" there was a fatal uncertainty. The court continued:

"If those words stood alone in the statute, there would be much force in that contention, but when we read the entire section together it clearly appears that the legislature used those general words to cover offenses similar to and belonging to the same general class as those denounced by the special or particular words which precede them."vo

Health v. McCoy, 125 IIl. 289 (unprofesional or dishonorable conduct according to "common judgment").

:7 Aiton v. Board of Med. Exam'rs, 13 Ariz. 354. 232 U. S. 733; Berry v. Statc (Tex. Civ. App.), 135 S. W. 631. See also cases cited in notes 47 and 48 , supra.

$\therefore$ Rev. Stats. 1890 , Sec. $8_{528}$, as amended. L.IwS I905, p. 215. Italics the writer's.

$\therefore$ State ex rel. v. Purl, 228 Mo. I.

cu See also Richardson v. Simpson, 88 Kans. 684. 


\section{Miscelinaneous Cases}

The general question has arisen in a wide variety of cases, and the results, as might be anticipated considering the nature of the problem, may not always seem consistent. The following expressions have been cleemed to have a workable meaning: "banking game" played for money ;ir "prize fight" or any "fight in the nature of a prize fight";" "conspiracy to clefraud"; ;i3 "molest or disturb" any meeting of inhabitants;" "which grossly disturbs the public peace or health",; "grossly injures the person or property" of another, or which "grossly disturbs the public peace or health," or which "openly outrages public decency," and is "injurious to public morals"; ;0 "any person who shall $* * *$ by speech $* * *$ encourage, justify, praise or incite * * * burning," etc. ; $^{\text {at }}$ druggist "who sells by retail without prescription the poisons mentioned must first satisfy himself that it is for a legitimate purpose"; $; 8$ "every window above the second story thereof shall be equipped with a suitable device which will permit the cleaning of the exterior of such windows without endangering life and limb. Provided, however, that such device need not be placed on any window that can be easily cleaned from within": $: 00$ motormen shall exercise "all possible care and vigilance" in approaching other cars, and have cars within "complete control."

c1 People v. Carroll, 80 Cal. 153 . See also State v. Gitt Lee, 6 Ore. 426 (cf. State v. Mann, 2 Ore. 238); Lowry v. State, I Mo. 722.

02 People v. Taylor, 96 Mich. 576 .

c3 Crawford v. U. S., 30 App. Cas. (D. C.) r.

6t State v. Askins, 28 Ind. 364. See also State v. Stuth, II Wash. 423.

is People v. Most, 73 N. Y. Supp. 220.

os State v. Lawrence, 9 Okl. Cr. Rep. I6, where accused was charged with violation of the statute in that in the presence of persons at a ball game he bet five dollars. The court said the common law furnished an adequate guide as to the meaning of the terms.

Gi State v. Quinlan, $86 \mathrm{~N}$. J. L. I20. "There is no organic law or rule of sound public policy that requires the legislature to define the meaning of words in common daily use," though the court might, of course, have to determine in a given case what amounted, for example, to "incitement."

is Katzman v. Commonwealth, 140 Ky. I24. Ly this time there may be suficient data on which to support such legislation.

ug Neave BIdg. Co. v. Roudebush, 96 Oh. St. 40 . This was a Cincinnati ordinance.

:0 Leis r. Cleve. Ry. Co., yor Oh. St. 162, involving a Cleveland ordinance. These two Ohio cases and State v. Schaeffer, 96 Oh. St. 215. uphold- 
On the other hand, the following are some of the many instances of language considered too uncertain: "commit any act injurious to the public health or public morals, or the perversion or obstruction of public justice, or the due administration of the law";in an offense to be guilty of "public indecency" $;^{72}$ an offense to be "a suspicious person"; $;$ definition in an ordinance of a vagrant as "any person *** who $* * *$ is not able to show a reasonable effort $* * *$ to secure some lawful employment"; "is "If any judge, justice of the peace, sheriff, or any other civil officer shall be guilty of any misdemeanor in the execution of either of their respective offices," he shall be fined; ;" "to punish indecent assaults" $;^{\text {is }}$ "all gambling devices";ir combining of two or more persons for the purpose of "mob vio-

ing the Ohio automobile speed law, furnish an interesting study in connection with Patten v. Alumnium Castings Co., 336 N. E. 426, referred to at the beginning of this paper. See also Toledo Cooker Co. v. Sniegowski, 105 Oh. St. 一, 136 N. E. ga4.

il Ex parte Jackson, 45 Ark. 158. Here the warrant under which the accused was arrested and held charged him with committing an act "injurious to the public morals" by leaving his wife, etc. It was said: "We cannot conceive how a crime can, on any sound principle, be defined in so vague a fashion. Criminality depends, under it, upon the moral idiosyncrasies of the individuals who compose the court and jury. The standard of crime would be ever varying, and the courts would constantly be appealed to as the instruments of moral reform, changing with all fluctuations of moral sentiment. The law is simply null. The constitution, which forbids ex post facto laws, could not tolerate a law which would make an act a crime, or not, according to the moral sentiment which might happen to prevail with the judge and jury after the act had been committed." The court would have been on safer ground if the last sentence had been omitted.

1: Jemnings v. State, 16 Ind. 335. Cf. Wall v. State, 23 Ind. Ijo.

is Stoutenberg v. Frazier, 16 App. Cas. (D. C.) 229. Here the court arrives at its conclusion after referring to the constitutional prohibitions of unreasonable searches and seizures and crucl and unusual punishments, saying it would be a cruel and unusual punishment to fine or incarcerate one about whom someone entcrtained suspicions!

it Ex parte Taft, - Mo. -, 225 S. IV. $45 \%$, noted in 21 Colvis. L. REv. 390 .

is State v. Gaster, 45 La. Ann. 636, reícrring to constitutional requirement that accused shall be informed of the nature of the charge.

"U State v. Comeaux, 13I La. 930. But statute punishing "assaults" is unobjectionable. Smith v. State, 58 Nieb. 531 .

is State v. Mann, 2 Ore. 238. But see State v. Gitt Lce, 6 Ore. 426 ; People v. Carroll, 80 Cal. 153. 
lence";is "oranges shall be considered unfit for shipment when frosted to the extent of endangering the reputation of the citrus industry if shipped" ;0 hauling on pikes or gravel roads during certain weather conditions more than one ton on "narrow tired" wagons. or on "broad tired" wagons more than two tons;" requirement that coal mine operators "employ a sufficient number of practical, experienced miners, to be designated as shot firers, whose duty it shall be to inspect and fire all blasts," and providing the employer shall be the judge of the qualifications of said miners ${ }^{*_{1}}$ requirement that street railway company provide sufficient cars to accommoclate those desirous of using the cars "without crowding said cars";" "reasonable" or "just" rate of fare $;^{83}$ prohibition of woodyard "within 150 feet of any inhabited portion of any residence district" ; 8 undertaking establishments declared nuisances per se if located and maintained "within those parts of the city occupied mainly for residences"; $;$ an offense to drive a "drove" of horned cattle in streets of city;" requirement that employers "make suitable provisions to prevent injury to persons who use or come in contact with machinery.".

is Augustine v. State, 4 I Tex. Crim. Rep. 59, 73. But in a civil action to recover damages from a county for the destruction of property "mob -violence" as used in a statute was of ascertainable meaning. Wakeley $v$. Douglas County, - Neb. -, 191 N. W. 337.

i0 Ex parte Peppers, - Cal. -, 209 Pac. 896. Power to an administrative officer to make regulations for application of act held bad.

${ }^{80}$ Cook v. State, 26 Ind. App. 278 . It was argued that the statute was unconstitutional. The court said no provision of the constitution was referred to, and therefore appellant had not presented a question of constitutionality. Nevertheless, the court held the statute void.

81 Glendale Coal Co. v. Douglas, - Ind. -, I37 N. E. 615. The court relied on the Fourteenth Amendment and the requirement of the state constitution that the accused shall be informed in writing of the nature and cause of the accusation.

82 United States v. Capitol Traction Co., 34 App. Cas. (D. C.) 392, sajing an indictment thereon would not inform accused of the nature and cause of the accusation.

${ }^{83}$ Louisville, etc., R. Co. v. Comm., 99 Ky. 132.

st City of St. Paul v. Schleh, Ior Minn. 42j. Cf. Pcople v. Oak Park. 266 III. 365; People v. Dow, 155 Mich. I15.

si Wlasem v. City of Fargo, - N. D. -, 190 N. IV. 546.

so McConvill v. City, 39 N. J. L. 38.

8i Held not a "lawful requirement" within Workmen's Compensation Act. Tolcdo Cooker Co. v. Sniegowski, 105 Oh. St. 一, 136 N. E. 90.4. 
Generally speaking, these decisions seem to be in accord with the doctrines observed by the federal decisions above discussed. Though the courts not infrequently purport to rest their conclusions upon constitutional provisions, this is not by any means universally or, perhaps, even usually true. It is submitted that where, as in Ohio, legislation cannot be declared unconstitutional by a mere majority of the court, it is perfectly permissible for a majority of the Supreme Court to declare an alleged act of the legislature ineffective because meaninglessly vague. The cases cited above in which the constitutional inhibitions regarding $e x$ post facto laws and cruel and unusual punishments were relied on seem obviously unsound, at least as to that part of the reasoning. Cases that go for review from the state to federal courts must, it seems, as pointed out, rest on the Fourteenth Amendment.

One of the most conmonly invoked constitutional provisions is that requiring that the accused be informed as to the nature of the accusation. Of course, an indictment or information based on these vague statutes may be defective on this ground. Ordinarily, however, it would be perfectly possible to draft a complaint that would not be deficient in this respect. While it is ordinarily true that it is sufficient to charge the offense in the terms of the statute, this rule does not apply where the statute prescribes the offense in language even of permissible generality. There the particular acts or circumstances relied upon as constituting the offense must be specified, ${ }^{83}$ and thus the accused has ample notice as to the charge against him. For instance, the accused in Ex parte Jackson ${ }^{\text {so }}$ knew perfectly well with what he was charged, but that did not save the statute.

The problem under discussion comes fundamentally to this: within its appropriate sphere the legislative body may prescribe rules of human conduct. This involves necessarily the statement of a rule and its promulgation. Not all collocations of words, even after subjection to the process of construction, can be said to lay down a rule, which, after all, is the very essence of a law. The test of the sufficiency of the language in this respect is necessarily lacking in precision. On the one side, the meaning need not be obvious to the most ignorant, and on the other, that the most learned are able to determine the sense of the language should not be sufficient. The

${ }^{83}$ See, for example, Smith v. State, - Ind. -, II5 N. E. 943.

se Supra, note jo. 
test, it is believed, should involve the standard of the mythical person of ordinary intelligence, but not standing necessarily in complete isolation and confined to the bare words of the statute. And written law not in a tongue in common use, it is submitted, would be of no effect because lacking the essential promulgation, even in the absence of constitutional requirement. 